\title{
Keanekaragaman Jenis dan Sebaran Ikan di Danau Buyan Bali
}

\author{
Gusti Agung Dwikhy Oka Taradhipaa*, I Wayan Arthana ${ }^{\mathrm{b}}$, Gde Raka Angga Kartika \\ a Program Studi Manajemen Sumberdaya Perairan, Fakultas Kelautan dan Perikanan, Universitas Udayana, Badung, Bali-Indonesia \\ * Penulis koresponden. Tel.: +62-821-4487-3075 \\ Alamat e-mail: dwikhyagung@gmail.com
}

Diterima (received) 20 Juni 2018; disetujui (accepted) 7 Agustus 2018

\begin{abstract}
Buyan lake is one of the lake in Bali, located in Pancasari Village, Sukasada, Buleleng. The research on the identification and distribution of fish species in Buyan lake are still scarce. Therefore, it is necessary to conduct research on identification and distribution of fish species in Buyan lake. This research was conducted from January to March 2018. Sampling was done for 3 times in 3 months. The location was determined by using purposive sampling in 4 stations. The fish was catched by using the gill net with 0,5 inchi, 2 inchi and 2,5 inchi size and the traditional fish trap, called bubu. The type of fishobtained in this research were 7 types with the total catch of 1024 fish. The fish that have biggest share is Xhiphophorus hellreri which was found in every research station, while the smallest share was Cyprinus carpio that can found only in station 1,2 and 3. The variant of fish located in Buyan lake is belong to the mid category, and both of uniformity and domination are belong to the the low category.
\end{abstract}

Keywords: Buyan Lake; Fish; Fish Distribution; Fish Diversity

\begin{abstract}
Abstrak
Danau Buyan merupakan salah satu danau yang terdapat di Provinsi Bali, yang terletak di kawasan Desa Pancasari, Kecamatan Sukasada, Kabupaten Buleleng. Penelitian yang membahas tentang identifikasi dan distribusi spesies ikan di Danau Buyan masih terbatas. Maka dari itu perlu dilakukan penelitian mengenai identifikasi dan distribusi spesies ikan di Danau Buyan. Penelitian ini dilakukan dari bulan Januari sampai bulan Maret 2018. Pengambilan sampel dilakukan sebanyak 3 kali dalam kurun waktu 3 bulan. Penentuan lokasi dilakukan dengan metode purposive sampling dengan mengambil 4 stasiun. Pengambilan sampel ikan dilakukan dengan menggunakan alat tangkap berupa jaring insang (gill net) dengan ukuran 0,5 inchi, 2 inchi, dan 2,5 inchi serta alat tangkap tradisional yang disebut bubu. Jenis ikan yang berhasil didapatkan selama penelitian di Danau Buyan terdiri dari 7 spesies dengan total ikan yang tertangkap sebanyak 1.024 ekor. Ikan yang memiliki sebaran paling banyak adalah Ikan Platy Pedang (Xhiphophorus hellreri) yang dapat dijumpai disemua stasiun penelitian dan ikan yang memiliki sebaran paling sedikit adalah Ikan Mas (Cyprinus carpio) yang hanya dijumpai pada stasiun 1, 2, dan 3. Keanekaragaman ikan yang terdapat di Danau Buyan termasuk kedalam kategori sedang, sedangkan baik keseragaman maupaun dominansi ikan, keduanya termasuk dalam kategori rendah.
\end{abstract}

Kata Kunci: Danau Buyan; Ikan; Keanekaragaman Ikan; Sebaran Ikan

\section{Pendahuluan}

Danau Buyan merupakan salah satu danau yang terdapat di Provinsi Bali, yang terletak di kawasan Desa Pancasari, Kecamatan Sukasada, Kabupaten Buleleng. Danau Buyan merupakan danau kaldera yang terbentuk dari hasil letusan gunung api dan runtuhan gunung beratan dan buyan purba. Potensi sumberdaya hayati dan non hayati yang terdapat di Danau Buyan dimanfaatkan dalam berbagai sektor, baik sektor perikanan maupun sektor lainnya. Pemanfaatan yang telah dilakukan di Danau Buyan antara lain yaitu: kegiatan perikanan (penangkapan dan budidaya), kegiatan manusia yang terdapat di Danau Buyan dapat mempengaruhi ekosistem yang terdapat di perairan tersebut dan juga mengakibatkan berubahnya kondisi lingkungan seperti halnya 
terjadinya pendangkalan serta penurunan tinggi permukaan air dan peningkatan laju sedimentasi (Fukomoto et al., 2015). Dengan kondisi lingkungan tersebut, Danau Buyan memiliki spesies ikan yang beranekaragam, mulai dari spesies ikan asli sampai spesies ikan hasil introduksi. Menurut Sravishta et al., (2018) terdapat 9 spesies ikan yang ditemukan di perairan Danau Buyan.

Rahardjo (2008) menyatakan bahwa ikan introduksi merupakan masuknya ikan spesies baru ke dalam suatu perairan dimana spesies tersebut sebelumnya tidak ada di perairan tersebut. Ikan asing yang terintroduksi kedalam suatu badan perairan dapat terjadi secara sengaja atau tidak sengaja. Keberadaan ikan introduksi di perairan dapat mengancam keberadaan ikan asli melalui fenomena hibridasi dengan ikan endemik, perusakan habitat, kompetisi pakan dan habitat, pemangsaan dan parasit atau penyakit (Courtenay dan Stauffer, 1984 dalam Rachmatika dan Wahyudewantoro, 2006). Hal tersebut juga dapat mempengaruhi keanekaragaman, kelimpahan spesies dan juga distribusi ikan yang terdapat di perairan tersebut.

Distribusi ikan merupakan suatu peristiwa persebaran ikan pada suatu tempat dan pada suatu waktu tertentu (Omar, 2012). Penyebaran ikan di perairan sangat ditentukan oleh faktor biotik, faktor abiotik, dan kegiatan manusia
(Ambarita, 2009). Dengan adanya perubahan ekologis terhadap perairan danau, maka diperkirakan memberikan pengaruh terhadap keanekaragaman makhluk hidup di dalamnya, khususnya ikan. Keanekaragaman jenis yang tinggi disuatu perairan menunjukkan keadaan komunitas yang baik, sebaliknya keragaman yang kecil berarti telah terjadi ketidakseimbangan ekologis di perairan tersebut (Koesbiono, 1979). Penelitian yang membahas tentang identifikasi dan distribusi spesies ikan di Danau Buyan masih terbatas. Maka dari itu perlu dilakukan penelitian mengenai identifikasi dan distribusi spesies ikan di Danau Buyan.

\section{Metode Penelitian}

\subsection{Waktu dan Tempat}

Penelitian ini dilaksanakan di kawasan konservasi Danau Buyan yang terletak di Desa Pancasari, Kecamatan Sukasada, Kabupaten Buleleng. Penelitian ini dilakukan dari bulan Januari sampai Maret 2018. Waktu pengambilan sampel dilakukan pada pagi hari, sedangkan pengambilan sampel dilakukan sebanyak 1 bulan sekali.

Penentuan lokasi dilakukan dengan metode purposive sampling dengan mengambil 4 stasiun dengan ketentuan yang berbeda (Gambar 1), yaitu sebagai berikut:

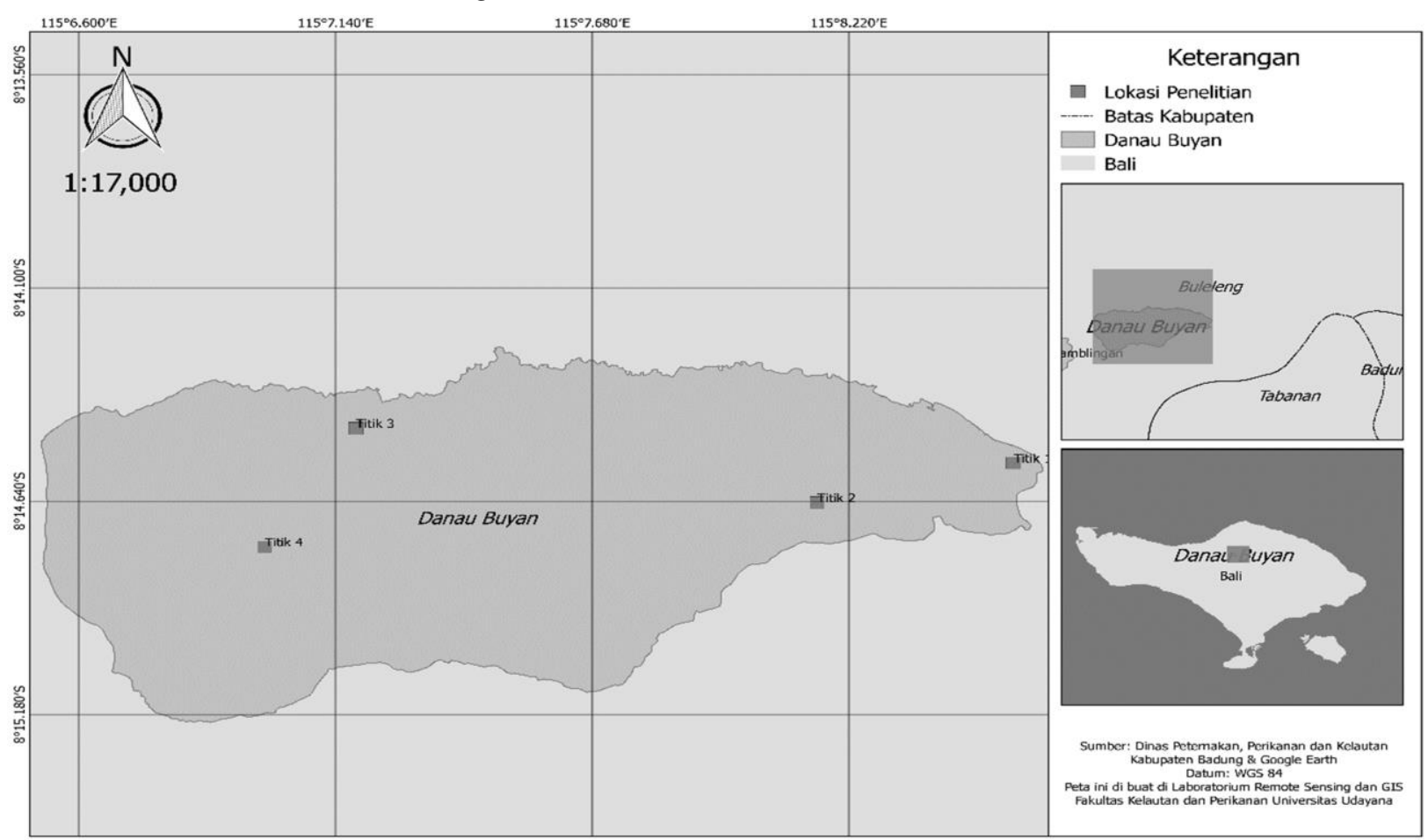

Gambar 1. Peta Lokasi Penelitian 
Stasiun 1 : daerah penangkapan ikan dengan jumlah tangkapan ikan paling banyak.

Stasiun 2 : daerah penangkapan ikan dengan jumlah tangkapan ikan paling beranekaragam.

Stasiun 3 : daerah penangkapan ikan dengan keanekaragaman dan jumlah tangkapan paling sedikit.

Stasiun 4 : bukan daerah penangkapan ikan.

\subsection{Teknik Pengambilan Sampel}

Pengambilan sampel dilakukan sebanyak 3 kali dalam kurun waktu 3 bulan. Pengambilan sampel ikan dilakukan dengan menggunakan alat tangkap berupa jaring (gill net) dengan ukuran 0,5 inchi, 2 inchi, dan 2,5 inchi serta bubu. Jaring dan bubu dipasang pada pagi hari lalu didiamkan selama 24 jam dan diangkat pada keesokan harinya. Kemudian, ikan hasil tangkapan dilepaskan dari jaring dan bubu, untuk kemudian ikan diawetkan dalam larutan alkohol 70\% dan didinginkan dalam cool box.

\subsection{Analisis Data}

\subsubsection{Indeks Keanekaragaman}

Analisis keanekaragaman menggunakan indeks keanekaragaman Shanon-Wiener dalam Soegianto (1994).

$H^{\prime}=-\sum\left(\frac{n i}{N}\right) \log \left(\frac{n i}{N}\right)$

Dimana $H^{\prime}$ adalah Indeks Keanekaragaman; $n i$ adalah jumlah individu; dan $\mathrm{N}$ adalah jumlah total individu.

$H^{\prime}<1 \quad=$ Keanekaragaman Rendah

$1<H^{\prime}<3 \quad=$ Keanekaragaman Sedang

$H^{\prime}>3 \quad=$ Keanekaragaman Tinggi

\subsubsection{Indeks Keseragaman}

Indeks keseragaman jenis dihitung berdasarkan (Odum, 1996), dengan rumus sebagai berikut:

$E=\frac{H^{\prime}}{H m a k s}$

Dimana $E$ adalah indeks keseragaman jenis; $H^{\prime}$ adalah indeks keanekaragaman Shannon-Wiener; dan $H$ maks adalah nilai keanekaragaman maksimum. Indeks keseragaman berkisar antara 01. Semakin kecil nilai $E$, semakin kecil pula keseragaman populasi yang berarti penyebaran jumlah individu setiap spesies tidak sama dan ada kecenderungan terjadi dominansi oleh satu spesies dari jenis yang ada. Semakin besar nilai $E$ tidak ada yang mendominasi antara jenis yang ada (Odum, 1996).

\subsubsection{Indeks Dominansi}

Dominansi spesies dapat dihitung dengan menggunakan rumus sebagai berikut (Odum, 1996).

$D=\Sigma(P i)^{2}$

Dimana $D$ adalah indeks dominansi fitoplankton; $\mathrm{Pi}$ adalah $(n i / \mathrm{N})$; $n i$ adalah jumlah individu ke-i; dan $N$ adalah jumlah total individu. Indeks dominansi berkisar $0-1$, bila $D$ mendekati 0 berarti dalam struktur komunitas biota yang diamati tidak terdapat spesies yang secara ekstrim mendominasi spesies lainnya dan bila $D$ mendekati 1 berarti di dalam struktur komunitas yang sedang diamati dijumpai spesies yang mendominasi spesies lainnya (Odum, 1996).

\section{Hasil dan Pembahasan}

Jenis ikan yang berhasil didapatkan selama penelitian di Danau Buyan terdiri dari 7 spesies dengan total ikan yang tertangkap sebanyak 1.024 ekor. Rincian spesies dan jumlah ikan yang berhasil ditangkap adalah sebagai berikut: Ikan Zebra (Amatitlania nigrofasciata) sebanyak 130 ekor yang terdapat pada semua stasiun, Ikan Nila (Oreochromis niloticus) sebanyak 75 ekor yang terdapat pada semua stasiun, Ikan Nilem (Osteochilus vittatus) sebanyak 154 ekor yang terdapat pada semua stasiun, Ikan Mas (Cyprinus carpio) 20 ekor yang terdapat hanya pada stasiun 1 , 2, dan 3, Ikan Platy Pedang varian 1 (Xhiphophorus helleri) sebanyak 543 ekor yang terdapat pada semua stasiun, Ikan Platy Pedang varian 2 (Xhiphophorus sp) sebanyak 56 ekor yang terdapat pada semua stasiun, dan Ikan Wader (Rasbora lateristriata) sebanyak 35 ekor yang terdapat pada semua stasiun. Data sebaran ikan pada semua stasiun dapat dilihat pada Gambar 2. Jenis ikan yang paling banyak ditemukan pada semua titik penelitian adalah dari jenis Ikan Platy Pedang varian 1 (Xhiphophorus hellreri). Tingginya 

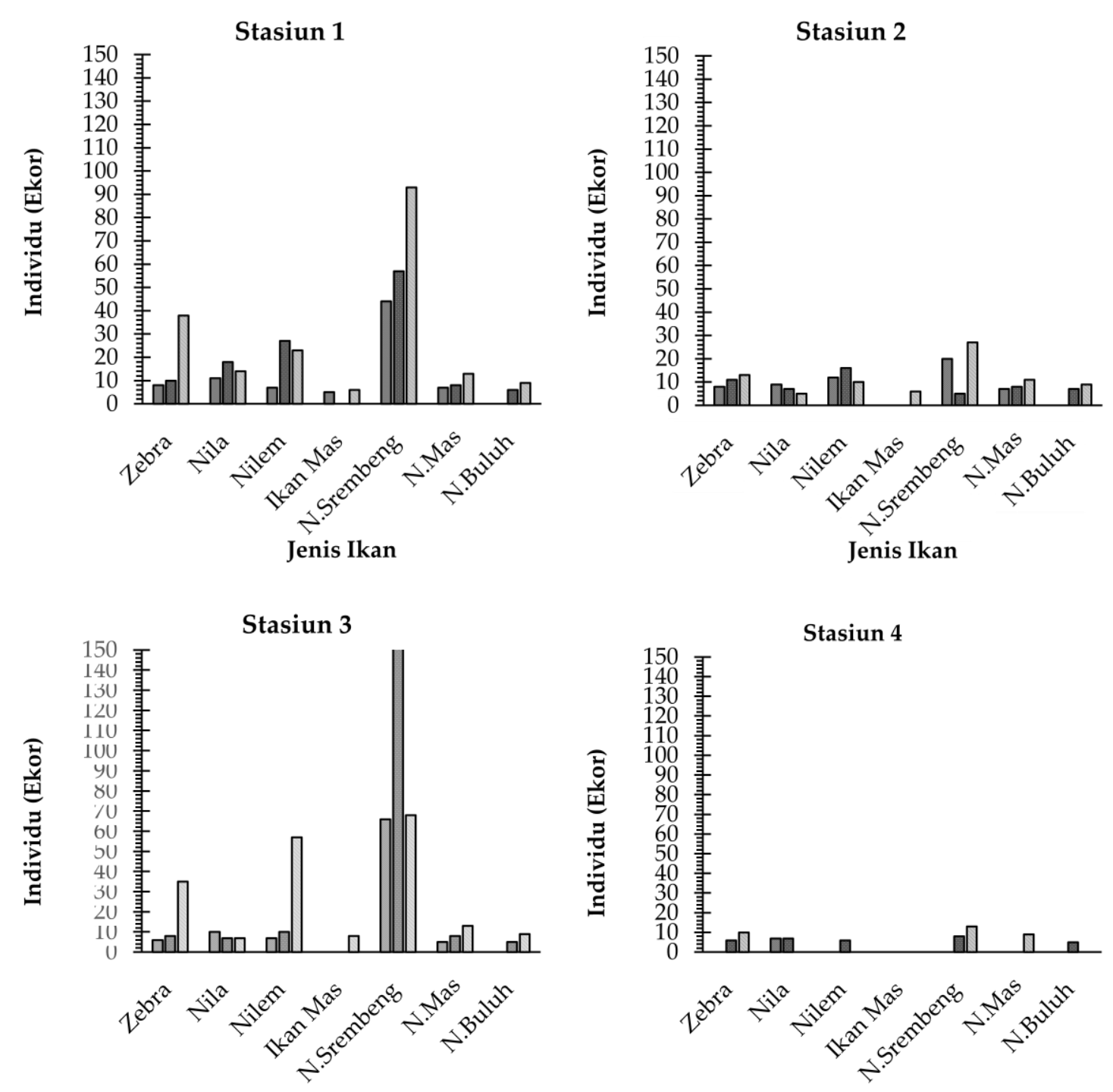

Jenis Ikan

Jenis Ikan

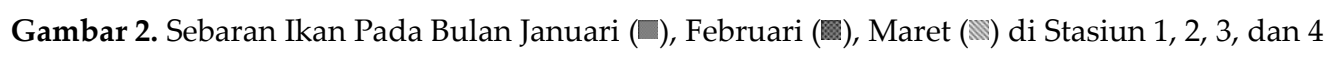

presentase hasil tangkapan ikan jenis platy pedang varian 1 pada semua titik diduga disebabkan karena ikan ini memiliki tingkat adaptasi yang sangat baik terhadap kondisi lingkungan. Menurut Timang et al., (2010), Ikan Platy Pedang merupakan ikan yang dapat beradaptasi dengan berbagai kondisi kualitas air. Tingkat reproduksi dari Ikan Platy Pedang ini sendiri juga dapat menyebabkan tingginya hasil tangkapan ikan ini disemua titik, dimana Ikan Platy Pedang dapat bereproduksi dengan cepat yaitu dalam selang waktu 1 bulan ikan ini akan dapat bereproduksi kembali. Febriayantoro (2014) berpendapat bahwa induk Ikan Platy Pedang betina dapat menghasilkan sekitar 80-125 ekor dengan interval pemijahan untuk memijah kembali terkadang membutuhkan waktu reporduksi sampai satu bulan. Proses reporduksi Ikan Platy Pedang berlangsung sangat cepat, Platy Pedang betina mampu memiliki kemampuan untuk menyimpan spermanya hingga 1 tahun, sehingga terkadang ditemukan Platy Pedang betina dapat berkali-kali melahirkan tanpa kehadiran jantan selama persediaan sperma masih tersedia. Anak Platy Pedang akan menjadi induk setelah berumur $3-5$ bulan (Timang et al., 2010). Selain itu, tingginya persentase hasil tangkapan dari ikan Platy Pedang varian 1 ini juga disebabkan karena nilai ekonomis dari Ikan Platy Pedang varian 1 ini lebih kecil dibandingkan dengan nilai ekonomis ikan lainnya, sehingga penangkapan Ikan Platy Pedang varian 1 ini lebih jarang dilakukan oleh masyarakat sekitar Danau Buyan. 


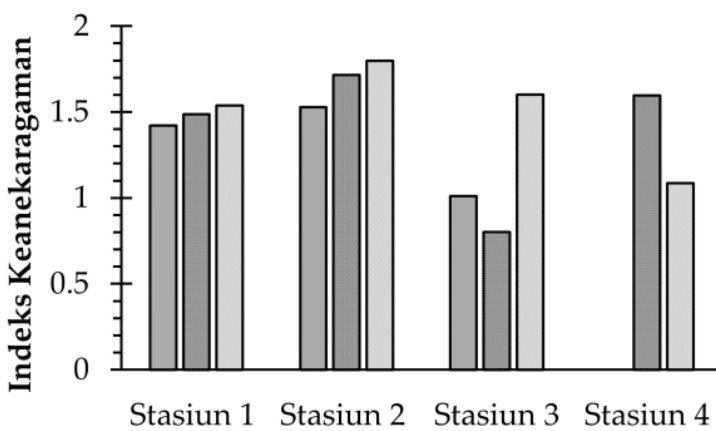

Lokasi Penelitian

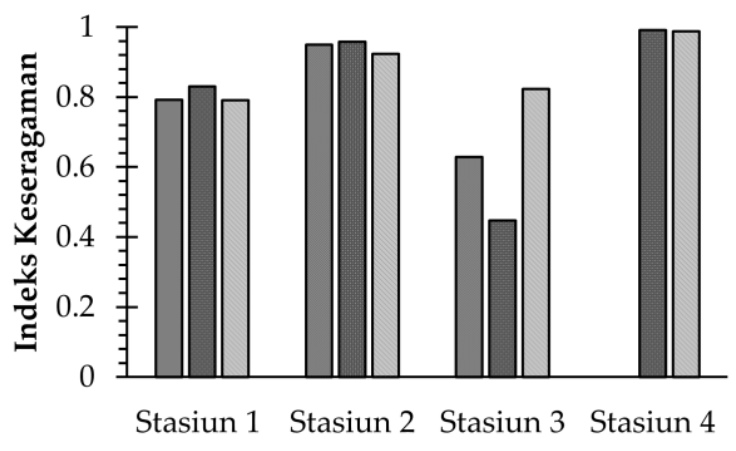

Lokasi Penelitian

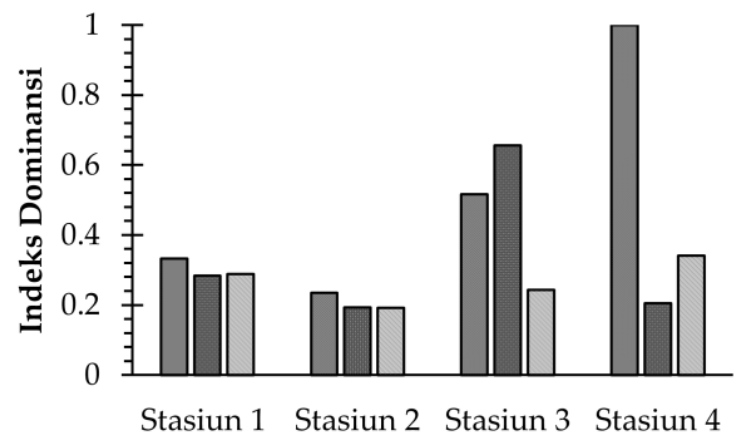

Lokasi Penelitian

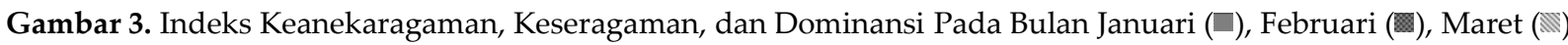

Terdapat 7 jenis ikan yang ditemukan diseluruh stasiun sampling di Danau Buyan. Hal ini dikarenakan pada keempat stasiun pengamatan memiliki kemiripan karakteristik habitat, hanya Ikan Mas yang tidak ditemukan pada semua lokasi penelitian terutama pada stasiun 4, hal ini dikarenakan pada keempat titik pengamatan memiliki kemiripan karakteristik habitat. Pada stasiun 4 yang memiliki kedalaman yang jauh lebih dalam dari stasiun 1,2, dan 3 sehingga spesies Ikan Mas pada stasiun 4 tidak ditemukan. Hal ini sesuai dengan pernyataan Khairuman et al., (2008) bahwa Ikan Mas biasa hidup diperairan tawar yang airnya tidak terlalu dalam, tidak terlalu deras, dan bersuhu hangat. Selain itu Susanto (2004), juga menyatakan bahwa Ikan Mas memiliki kebiasaan makan sebagai bottom feeder atau mencari makan pada dasar perairan. Ikan Mas dialam juga hidup menepi sambil mengincar makanan berupa binatang-binatang kecil yang biasanya hidup dilapisan lumpur tepi danau atau sungai.

Berdasarkan hasil analisis indeks keanekaragaman ikan (Gambar 3) selama penelitian, secara keseluruhan indeks keanekaragaman ikan yang terdapat di Danau Buyan termasuk dalam kategori rendah hingga sedang. Tinggi rendahnya nilai indeks keanekaragaman tergantung oleh variasi jumlah individu setiap spesies ikan yang berhasil tertangkap, jika semakin besar jumlah spesies ikan dan variasi jumlah individu tiap spesies maka tingkat kenaekaragaman ikan dalam suatu ekositem perairan tersebut semakin besar, demikian juga sebaliknya, jika semakin kecil jumlah spesies ikan dan variasi jumlah individu tiap spesies yang tertangkap maka tingkat keanekaragaman ikan didalam suatu ekosistem perairan juga akan semakin kecil (Sriwidodo et al., 2013). Suatu komunitas dikatakan memiliki keanekaragaman spesies yang tinggi apabila terdapat banyak spesies dengan jumlah individu masing-masing spesies relatif merata, dengan kata lain apabila suatu komunitas hanya terdiri dari sedikit spesies dengan jumlah individu yang tidak merata, maka komunitas tersebut memiliki keanekaragaman yang rendah (Barus, 2004). 
Dari hasil perhitungan nilai indeks keseragaman (Gambar 3) ikan selama penelitian, secara keseluruhan indeks keseragaman ikan yang terdapat di Danau Buyan termasuk dalam kategori sedang. Indeks keseragaman menggambarkan sebaran dari kepadatan ikan-ikan pada suatu ekosistem dimana ikan tersebut ditangkap dan selanjutnya digunakan sebagai gambaran tingkat dominansi suatu jenis spesies dan juga kestabilan ekosistem (Siagian, 2009), maka dari itu keseragaman jumlah ikan pada titik 4 bulan Februari lebih tinggi dibandingkan titik pengamatan yang lainnya. Sebaliknya, nilai indeks keseragaman ikan pada titik 4 pada bulan Januari lebih rendah, yang berarti sifat mendominasi ikan dari kelompok spesies tertentu lebih tinggi dibandingkan dengan stasiun lainnya. Menurut Odum (1996), Indeks keseragaman berkisar antara $0-1$, semakin kecil nilai $E$, semakin kecil pula keseragaman populasi yang berarti penyebaran jumlah individu setiap spesies tidak sama dan ada kecenderungan terjadi dominansi oleh satu spesies dari jenis yang ada. Semakin besar nilai $E$ tidak ada yang mendominasi antar jenis yang ada.

Nilai indeks dominansi jenis ikan (C) secara keseluruhan termasuk dalam kategori rendah. Indeks dominansi tertinggi terdapat pada titik 4 bulan Januari yang berarti terdapat satu jenis spesies yang mendominansi dan diikuti dengan nilai indeks keseragaman jenis ikan yang rendah, sedangkan nilai indeks dominansi terendah ditemukan pada titik 4 bulan Februari, yang berarti tidak ada spesies yang mendominasi pada titik tersebut dan diikuti dengan nilai indeks keseragaman jenis ikan yang tinggi. Menurut Odum (1996), indeks dominansi berkisar 0-1, bila $D$ mendekati 0 berarti dalam struktur komunitas biota yang diamati tidak terdapat spesies yang secara ekstrim mendominasi spesies lainnya dan bila $D$ mendekati 1 berarti di dalam struktur komunitas yang sedang diamati dijumpai spesies yang mendominasi spesies lainnya.

\section{Simpulan}

Ikan yang memiliki sebaran paling banyak adalah Ikan Platy Pedang varian 1 (Xhiphophorus hellreri) yang dapat dijumpai disemua stasiun penelitian dan ikan yang memiliki sebaran paling sedikit terdapat pada Ikan Mas (Cyprinus carpio) yang tidak dijumpai pada stasiun 4. Keanekaragaman ikan yang terdapat di Danau Buyan termasuk kedalam kategori sedang, keseragaman termasuk dalam kategori rendah, dan dominansi ikan termasuk dalam kategori rendah.

\section{Ucapan terimakasih}

Ucapan terimakasih diucapkan kepada Bapak Winardi dan kelompok nelayan Danau Buyan yang telah membantu dalam pengambilan data penelitian.

\section{Daftar Pustaka}

Ambarita, R. (2009). Keanekaragaman dan Distribusi Ikan di Hulu Sungai Asahan Porsea. Skripsi. Medan, Indonesia: Dapartemen Biologi, Fakultas Matematika dan Ilmu Pengetahuan Alam, Universitas Sumatera Utara.

Barus, T. A. (2004). Faktor-faktor Lingkungan Abiotik Dan Keanekaragaman Plankton Sebagai Indikator Kualitas Perairan Danau Toba (Environmental Abiotic Factors and the Diversity of Plankton as Water Quality Indicators in Lake Toba, North Sumatera, Indonesia). Jurnal Manusia dan Lingkungan, 11(2), 64-72.

Courtenay, W. R., \& Stauffer, J. R. (1984). Distribution, biology, and management of exotic fishes. USA: Johns Hopkins University Press.

Dinas Pekerjaan Umum Provinsi Bali. (2000). Pola Pengamanan dan Konservasi Danau Buyan dan Danau Tamblingan dan lain-lain di Propinsi Bali. Bali: PT. Tata Guna Patria.

Febriyantoro, D. (2014). Pengamatan Pergerakan Sirip-Sirip Ikan dan Mekanisme Ikan Mengambil Makanan dan Laju Menghancurkan Makanan di Dalam Lambung. Skripsi. Makasar, Indonesia: Fakultas Perikanan dan Ilmu Kelautan. Universitas Hasanuddin.

Fukumoto, Y., Li, X., Yasuda, Y., Okamura, M., Yamada, K., \& Kashima, K. (2015). The Holocene environmental changes in southern Indonesia reconstructed from highland caldera lake sediment in Bali Island. Quaternary International, 374, 15-33.

Khairuman, SP., Dodi, S., Gunadi B. (2008). Budidaya Ikan Mas Secara Intensif. Jakar, Indonesia: Agromedia Pustaka. 
Koesbiono. (1979). Dasar-Dasar Ekologi Umum, Bagian IV (Ekologi Perairan). Sekolah Pasca Sarjana Program Studi Lingkungan. IPB, Bogor.

Odum, E. P. (1996). Dasar-dasar Ekologi. Yogyakarta: Gadjah Mada University Press.

Omar, S. B. A., \& Bin, S. (2012). Dunia ikan. Yogyakarta, Indonesia: Gadjah Mada University Press.

Rachmatika, I., G. Wahyudewantoro.(2006). Jenisjenis ikan introduksi di perairan Jawa Barat dan Banten: Catatan tentang taksonomi dan distribusinya. Jurnal Iktiologi Indonesia, 6(2), 9397.

Rahardjo, M.F. (2008). Perkembangan IPTEK dalam Pemacuan Sumberdaya Ikan. Dalam Rahardjo et al. (eds). Prosiding Forum Nasional Pemacuan Sumberdaya Ikan I. Pusat Riset Perikanan Tangkap bekerjasama dengan Departemen MSP-IPB. Pusat Penelitian Biologi LIPI. dan Masyarakat Iktiologi Indonesia: 45 - 49.
Siagian, C. (2009). Keanekaragaman dan Kelimpahan Ikan Serta Keterkaitannya Dengan Kualitas Perairan di Danau Toba Balige Sumatera Utara. Tesis. Medan, Indonesia: Universitas Sumatera Utara.

Sravishta, I. M. S. K., Arthana, I. W., \& Pratiwi, M. A. (2018) Pola dan Parameter Pertumbuhan Ikan Tangkapan Dominan (Oreochromis niloticus, Osteochilus sp. dan Xiphophorus helleri) di Danau Buyan Bali. Journal of Marine and Aquatic Sciences, 4(2), 204-212.

Sriwidodo, D. W. E., Budiharjo, A., \& Sugiyarto S. (2013). Keanekaragaman jenis ikan di kawasan inlet dan outlet Waduk Gajah Mungkur Wonogiri. Jurnal Bioteknologi, 10(2), 43-50.

Susanto, H. (2004). Budidaya Ikan di Pekarangan. Penebar Swadaya, Jakarta. 150 hal.

Timang, Y., Sitti, R. A., Muhammad, R. A dan Rispa, P. (2010). Mekanisme Pergerakan SiripSirip Ikan. Skripsi. Makasar, Indonesia: Universitas Hasanuddin. 